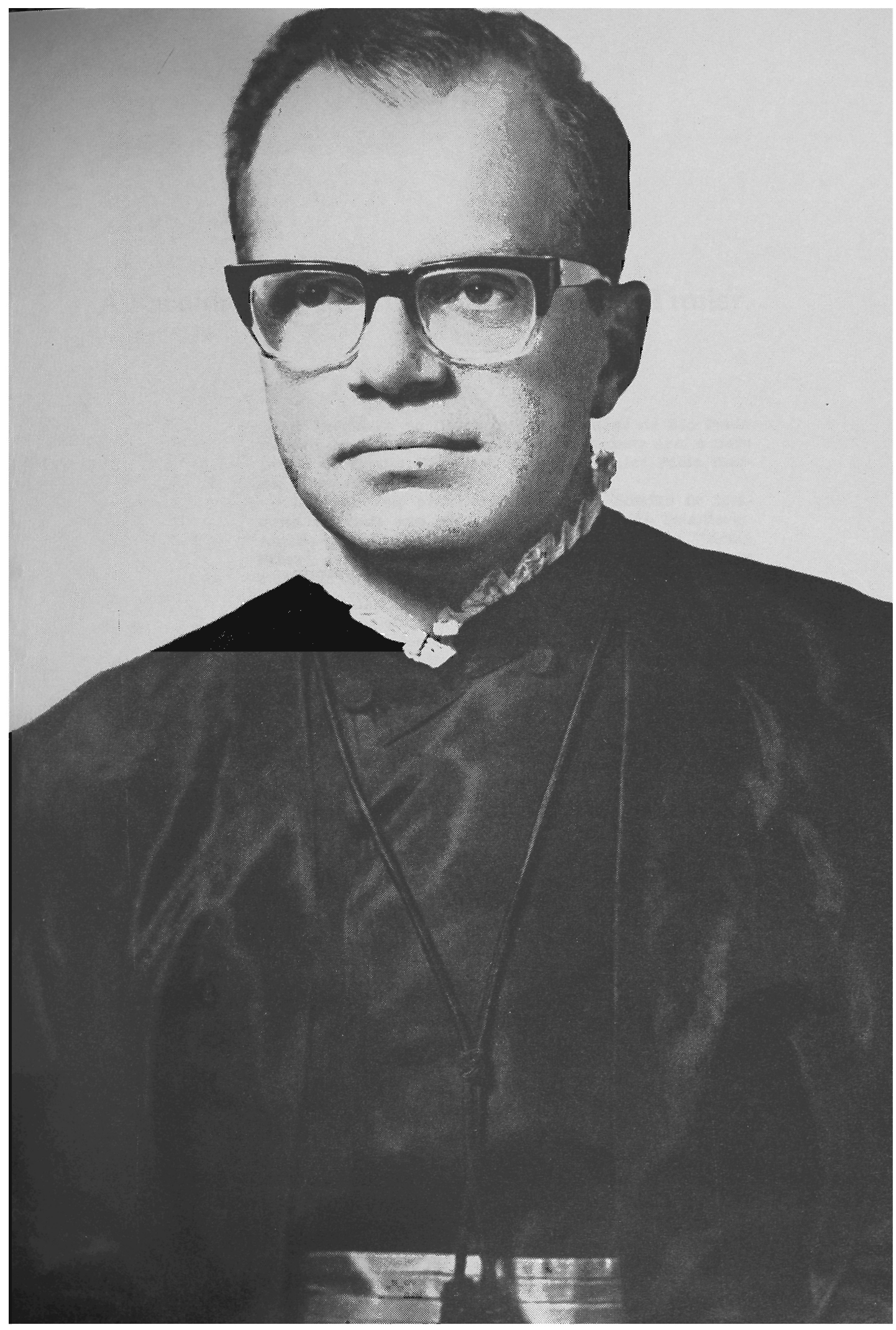


Professor Doutor Fábio Konder Comparato, Titular de Direito Comercial. 


\title{
A Faculdade de Direito Recebe mais um Titular.
}

\author{
A Redação.
}

\begin{abstract}
A Faculdade de Direito da Universidade de São Paulo recebeu em seu doutoral, aos 20 de maio deste ano, o novo títular de Direito Comercial, Professor Doutor Fábio Konder Comparato.

Saudado pelo professor José Ignácio Botelho de Mesquita, responde com um libelo contra o Estado Totalitário. Analisa a transformação do "Jurisprudente" em "Homo Faber", sua consequiência na política moderna, que reduz - "Forum" a mercado, e legitima a violência "enquanto degrada o poder" como método normal de governo.

Denuncia, ainda, o Estado Totalitário como inimigo da legalidade, aliciador de juristas a serviço do terror e do arbitrio. Declara, então, sua plataforma jurisdocente com a promessa de atuar contra esse servilismo jurídico, dentro e fora "desta Casa do Direito".
\end{abstract}

\section{O Professor.}

Fabio Konder Comparato nasceu em Santos, neste Estado, aos 8 de outubro de 1936. E filho de Antônio Comparato e de Maria Sulamita Konder Comparato.

Bacharelou-se por esta Faculdade em 1959. Logo depois, em 1961 e 1962, faz o curso de Direito Comparado no Instituto de Direito Comparado na Universidade de Paris, com aprovação em todos os exames.

De 1962 a 1963 freqüenta a Faculdade de Direito e das Ciências Econômicas da mesma Universidade, e, com a tese Essai d'Analyse Dualiste de l'Obligation en Droit Privé, recebe o título de doutor, sendo laureado com o Prêmio Louis Milliot. 
Exerce, ainda, de agosto de 1963 a março de 1964 o cargo de Secretário Jurídico do Supremo Tribunal Federal em Brasília.

Com bolsa de estudos concedida pelo Ministério Francês das Relações Exteriores, faz estágio de pesquisa sobre métodos jurídicos da planificação econômica em diversos ministérios da capital francesa, de 19 de outubro de 1964 a 30 de janeiro de 1965.

Retornando ao Brasil, submete-se à livre docência de Direito Comercial nesta Faculdade, em concurso de títulos e provas, sendo aprovado por unanimidade. Desde então leciona Direito Comercial no curso noturno, com algumas interrupções, até dezembro de 1971. Em 1973, mediante concurso de títulos, é nomeado professor adjunto ao Departamento de Direito Comercial.

Além de suas atividades docentes é diretor executivo da Revista de Direito Mercantil, Industrial, Econômico e Financeiro, publicada pelo Instituto de Direito Comercial Comparado, e Biblioteca Tullio Ascarelli e Direito Econômico e Financeino desta Faculdade.

Participou da Comissão Elaboradora e Revisora do Anteprojeto de Código Civil Brasileiro, na parte referente ao Contrato de Seguro. Foi diretor e chefe do Departamento do Contencioso do Banco de Indústria de São Paulo, de 1970 a 1975. e é diretor da Metal Leve S.A. Indústria e Comércio, desde abril de 1975.

E membro da Societé de Législation Comparée de Paris, do Instituto dos Advogados de São Paulo, do Instituto Brasileiro de Direito Comercial Comparado e Biblioteca Tullio Ascarelli desta Faculdade e do Conselho Jurídico da Associação Comercial de São Paulo.

O professor Konder Comparato publicou densa bibliografia: livros, artigos doutrinários, conferências, Comentários de jurisprudência e pareceres sobre Direito Comercial e Direito Comparado, que se publica a seguir: 


\section{Bibliografia.}

\section{A. Livros}

1. Essat d'Analyse Dualiste de l'obligation en Droit Privé (Prêmio Louis Milliot, da Faculdade de Direito e das Ciênclas Econômicas da Universidade de Paris), Paris, Libratrie Dalloz, 1964.

2. O Seguro de Crédito, São Paulo, Editora Revista dos Tribunais, 1968.

3. Aspectos Jurídicos da Macro Empresa, São Paulo, Editora Revista dos Tribunais, 1970 .

4. O Poder de Controle da Sociedade Anónima. São Paulo, Editora Revista dos Tribunais, 1976.

B. Artigos Doutrinários e conferências:

1. O Indispensável Díreito Econômico - Revista dos Tribunais, 353/14.

2. Concorrência Desleal - Revista dơs Tribunais, 375/29.

3. Contrato de Leasing - Revista dos Tribunais, 389/7.

4. Obrigaçōes de melos, de resultado e de garantia - Revista dos Tribunais, $386 / 26$.

5. Insider Trading: Sugestóes para uma moralização do nosso mercado de capitals - na Revista de Direlto Mercantil, n.0 2, ano X, nova série, 1971.

6. Novas formas Jurídicas de concentração empresarial - na Revista de Direito Mercantil, n.o 5, ano XI, nova série, 1972, e na obra coletiva "Fusōes e Incorporaçóes", São Paulo, Editora Mestre Jou, 1972.

7. Factoring - na Revista de Direito Mercantil, n.० 6, ano XI, nova série, 1972 .

8. O regime Jurídico do cheque na Lei Untforme de Genebra - na Revista de Direito Mercantil, n.० 7, ano XI, nova série, 1972.

9. Les factures protestables, étude comparative de droit français et brésilien na Revue Trimestrielle de droit comercial, 1968, n.0 1.

10. Le Tribunal Maritime au Brésil - em Le Droit Maritime Français, n. ${ }^{\circ}$ 241, janeiro de 1969.

11. Poder de controle na sociedade anônima: na Revista de Direito Mercantll, n. 9, ano XII, nova série, 1973.

12. A proteção do consumidor: Importante capítulo do direito econômico na Revista de Direito Mercantil, n.0 15/16, ano XIII, nova série, 1974.

13. Franquia e concessão de venda no Brasil: da consagração ao repúdio - na Revista de Direlto Mercantil, n.o 18, ano XIV, nova série, 1975.

C. Comentários de jurisprudência $e$ notas de atualidades:

1. Falência - Interpretação analógica: na Revista de Direlto Mercantil, n.0 1 , ano $\mathrm{X}$, nova sérle, 1971. 
2. Seguro de responsabilidade civil - Ação direta da vitima do dano contra - segurador - Inadmissibilidade: Revista de Direito Mercantil, n.॰ 1, ano $\mathrm{X}$, nova série, 1971 .

3. Nota introdutiva a Projeto holandês sobre a contabilidade das empresas: na Revista de Direito Mercantil, n.0 2, ano $\mathrm{X}$, nova série, 1971.

4. Abertura de crédito - Nulidade de cláusula contratual: na Revista de Direito Mercantil, n. ${ }^{\circ}$, ano $\mathrm{X}$, nova série, 1971.

5. Sociedade comercial - Marido e Mulher - Embargos de tercelros - Improcedência - Recurso provido: na Revista de Direlto Mercantil n.0. 3. ano $X$, nova série, 1971 .

6. Nota introdutiva ao Projeto de lei do Conselho das Comunidades Européias para a regulamentação da sociedade anônima européia: na Revista de Direito Mercantil, n.os 3 e 4, ano $\mathrm{X}$, nova série, 1971 .

7. Substituto ao capítulo referente ao contrato de seguro no Anteprojeto de Código Civil: na Revista de Direito Mercantil, n.० 5, ano XI, nova série. 1972 .

8. Seguro - cláusula de rateio proporcional - Juridicidade: na Revista de Direito Mercantil, n.0 7, ano XI, nova série, 1972.

9. Seguro de vida em grupo - Segurado, vitima de tumor maligno, falecido poucos meses após o contrato - Boa-fé - Falta - Alegação pela seguradora - Inadmissibilidade - Exame médico não exigido, nem outros esclarecimentos sobre as declaraçōes prestadas - Ação executiva procedente: na Revista de Direito Mercantil, n.0 10, ano XII, nova série, 1973.

10. Sociedade anônima - Controle acionário exercido por diretor - Alienaçăo no curso do exercício social - Pretensão do alienante de haver uma parte de remuneração percentual sobre os lucros líquldos, prevista no exercício do mandato: na Rev. Dir. Mercantll, n.0 11, ano XIr, nova série, 1973 .

11. Concordata preventiva - Sociedade corretora de titulos e valores moblliários: na Revista de Direito Mercantil, n.o 12, ano XII, nova série, 1973 .

12. Anteprojeto de lei de sociedades por ações - na Rev. Dir. Mercantil, n. ${ }^{\circ}$ 17, nova série, 1975.

13. Projeto de Código Civil - na Rev. Dir. Mercantil, n.॰ 17, nova sérłe, 1975.

D. Pareceres

1. Vigência das Convenções de Genebra sobre letras de câmbio, promissórlas e cheques: Revista dos Tribunais, 390/48.

2. Nota promissória rural - Inconstitucionalidade e revogação dos arts. 107 e segs. do Estatuto da Lavoura Canavieira: Revista dos Tribunais, 412/43.

3. Seguro de crédito financeiro e fraude do financtado: Revista dos Tribunais, $415 / 43$. 
4. Allenação de bens de sociedade anônima - Ato praticado pela diretoria, sem poderes - Impedimento dos diretores de votarem em assembléla geral convocada para sua ratificação: Revista dos Tribunals, 428/160.

5. Falência - Requerimento com base em créditos trabalhistas - Desnecessidade da renúncia ao privilégio para exercicio do direlto: Revista dos Tribunais, 432/53.

6. Falência - Legitimidade da Fazenda Pública para requerê-la: Revista dos Tribunais, $442 / 48$.

7. Caucionamento de cheque bancário: Revista dos Tribunais, 449/63.

8. Sociedade por cotas de responsabilidade limitada: Revista dos Tribunals, $473 / 33$.

\section{A Titularidade e a Recepção.}

Com os títulos universitários e docentes conquistados nesta Faculdade e na Universidade de Paris, além de outros, Fabio Konder Comparato concorre à titularidade de Direito Comercial, aberta pela aposentadoria do Professor Philomeno Joaquim da Costa.

Aprovado por unanimidade, é nomeado a 9 de janeiro do corrente ano, e recebido no doutoral aos 20 de malio, em sessão solene da Congregação realizada no salão nobre, sob a presidência do Senhor Diretor, Professor Doutor Ruy Barbosa Nogueira.

Introduzido no recinto pelos professores Miguel Reale, Washington de Barros Monteiro e Sílvio Marcondes, é saudado em nome da Congregação pelo professor José Ignácio Botelho de Mesquita, que proferiu o seguinte discurso:

\section{Discurso de saudação de José Ignácio Botelho de Mesquita.}

Não há verdadeira riqueza, senão a de homens. "Il n'est de richesse que d'hommes". Este axioma abre o prefácio com que Andre Tunc, Professor da Faculdade de Direito de Paris, introduz os leitores de Fabio Konder Comparato à sua obra intitulada Essai d'analise dualiste de l'obligation en Droit Privée. 
Foi esta sua tese de doutoramento na Universidade de Paris. Pode, por isto, dizer-se que, vindo à luz assinalou o local, a data e o modo do nascimento de Fabio Comparáto para o mundo da Ciência do. Direito.

Bem posso imaginar, portanto, o que teria significado para ele, o prêmio Louis Milliot com que a Universidade de Paris laureou esta obra. Não ainda, por certo, uma consagração; mas indiscutivelmente um notável batismo.

Não seria lícito, contudo, dizer-se que tivesse sido um batismo ou uma vitória, celebrados em terra estranha. A França, sua cultura, seus juristas, suas instituições, tornaram-se desde cedo familiares ao jovem estudioso.

Aliás, a leitura daquela tese revela não apenas familiaridade, conhecimento profundo. Revela mais, muito mais. Demonstra aquele conhecimento próprio de quem ama a força e o vigor de quem apaixonou-se pelo estudo que realizava, parte talvez do amor maior que conheceu na França, e sobre a qual alicerçou a sua vida.

Esta aurora, porém, que se levantava em Paris, às margens do Sena, fora precedida de uma longa e fecunda formação, que mergulhava suas raízes no ambiente cultural que $\mathrm{F}_{\mathrm{A}-}$ bio Comparato respirara desde o berço.

Muito cedo revelou ele uma personalidade marcante. Lembro-me, dos tempos de colégio, que Fabio Comparato se tornara conhecido até mesmo por aqueles, como eu, que sendo mais velhos, não freqüentávamos as mesmas classes.

Então, como ainda hoje, um certo mistério impedia um pleno conhecimento da personalidade daque estudante extremamente reservado. Não era possível conhecê-lo mais que pelos resultados de seus trabalhos.

Fabio Comparato destacava-se como aluno estudioso e inteligente, mas nos intrigava com a sua capacidade de aliar, 
à dedicação aos estudos escolares, a dedicação não menor com que se entregava a outros estudos mais amplos, como fazia, por exemplo, em relação à arte, notadamente à música.

Naquela época, em que a todos, por igual, nos inquietavam as forças desordenadas da adolescência, pouco podíamos compreender daquela personalidade que, à luz e ao calor dos mesmos sóis, embora mais rapidamente do que nós, ia ao encontro de sua maturidade.

Pouco compreendíamos, então, do sentido profundamente humanístico que estava orientando e acelerando a sua formação; em perfeita harmonia, aliás, com as estruturas internas de sua jovem personalidade.

Foi somente depois, bem depois, anos mais tarde, quando F'́́bio Comparato iniciou-se nos escritos jurídicos, revelando neles o seu intelecto de cientista, a sua alma de cristão e católico, a sua sensibilidade de artista, foi somente então que pudemos compreender o que se passara naqueles distantes anos de formação, e que o preparara de tal modo para os êxitos que marcariam a sua carreira futura.

Ele havia procurado viver a sua realidade, o seu mundo, de forma global. Não o dividia em compartimentos, não o departamentaliza; através da ciência, via os fatos e, mirando os fatos, entrevia a ordem de que se achavam impregnados.

Não creio que seria avançar conjecturas excessivas, dizer que essa necessidade de uma informação global a respeito do Homem e de sua Cultura é que teria conduzido seus passos a Paris, tal como os dos peregrinos atraídos pelos átrios das catedrais.

E a partir daí, que a obra de Fábio Comparato passa a desvendar as características que informam a sua personalidade.

Há em suas obras uma preocupação fundamental, básica, que as inspira e domina. 
Pode dizer-se, de um modo geral, que Fábio Comparato não escreve apenas para transmitir conhecimentos. Ele o faz. com a preocupação de aperfeiçoar os institutos jurídicos, e de aperfeiçoá-los de um modo muito peculiar, muito seu, diríamos até mesmo muito raro.

Os juristas, em grande parte, costumam padecer do vezo, criticado por Fábro Comparato, de pensar que

"... o Direito seria o reino da lógica e da esquematização de categorias, cuja pureza repudia qualquer contacto com a realidade fenomenal. As instituições jurídicas conservariam uma lógica interna absolutamente imutável, e todo o esforço da "jurisprudentia" consistiria exatamente na captação desta forma ideal pela qual elas se manifestam" (O Indispensável Direito Econômico, "in" Rev. dos Tribs. v. 353 p. 25$)$.

Pois bem, a obra de Fábio Comparato revela uma preocupação, um esforço, dirigidos em sentido diametralmente oposto a este. Parafraseando-o, poderíamos dizer que toda a obra deste jurista representa um esforço no sentido de demonstrar que a pureza da realidade fenomenal é que repudia qualquer esquematização de categorias puramente lógicos.

Fábio Comparato procura ao nível da realidade, sempre o mais junto a ela que for possível, encontrar as soluções para os problemas que o Direito oferece.

Desde a sua já citada tese de doutoramento, vem ele trilhando esse caminho. Aquilo que ele chamou, modestamente, de Ensaio de Análise Dualista da Obrigação, não foi outra coisa senão já a demonstração mais cabal, extraída da própria realidade jurídica francesa, de que outra explicação satisfatória para o conceito de obrigação não haveria, senão a que emergia da análise dualista. 
Ora, convém notar que a doutrina francesa, então dominante, obstinava-se em desconhecer a validade desse enfoque do conceito de obrigação, sem embargo dos favores de que já gozava em outros países.

A tese de Fábio Comparato, dentro desse panorama. implicava uma contribuição para o aperfeiçoamento da doutrina a partir dos dados fornecidos pelo próprio sistema jurídico.

Essa mesma preocupação vamos encontrar em outros trabalhos como nos artigos O Indispensável Direito Econômico e Insider Trading - Sugestões para a moralização do nosso mercado de Capitais (o primeiro já citado e o segundo "in" Revista de Direito Mercantil, 2/14).

Neste último, ele toma nas mãos um tema da mais viva atualidade, precisamente na época em que a especulação nas nossas Bolsas de Valores principiava a atingir as mais diversas camadas da população, prestes a sucumbir sob as consequiências desastrosas que seguir-se-iam logo após. E ilumina essa realidade à luz da experiência do direito norte-americano para mostrar a possibilidade de uma regulamentação jurídica que, moralizando o mercado de capitais, o trouxesse para o plano das realidades socialmente úteis ao nosso País.

E o vemos também imbuído do mesmo propósito quando sistematiza, em sua tese de concurso a professor titular, 0 problema do poder de controle nas sociedades anônimas.

F'́́bio Comparato não censura, não critica, não opõe apenas argumentos contra argumentos. Ele mergulha sua investigação na experiência concreta e a partir dela constrói o sistema. Mostra a viabilidade da regulamentação jurídica e surpreende os teóricos com uma nova harmonia extraída do fato vivido e experimentado.

Quando enfrenta, por exemplo, o candente problema proposto pela teoria da desconsideração da personalidade jurídi- 
ca (a "disregard of legal entity"), não o faz só para condenar os desvios a que abuso da personalidade jurídica tem conduzido a aplicação do direito, mas, sim, para mostrar em que termos seria possível e justo definir e disciplinar juridicamente a responsabilidade do grupo econômico e do controladior das empresas transparentes.

(Enfim, Fábio Comparàto parece nesses momentos a síntese mais viva da velha máxima, de que mais vale acender uma vela que amaldiçoar a escuridão.)

Ora, meus senhores, quando vemos, nos dias que correm, acentuar-se violentamente o descompasso entre as categorias ultrapassadas, que viciam o conhecimento dos responsáveis pela aplicação do direito, e realidade a que devem julgar, a obra deste jovem professor, qual um ariete impossível de sofrer contenção, arremete firme e fundo contra as portas do ceticismo, contra portais das doutrinas inertes, contra o esnobismo fátuo das novidades inconsistentes, como a forçar a passagem da luz e do ar puro, móstrando ao sol do dia, em sua nudez magnífica, a carne viva de uma realidade a clamar por direito e por justiça. Casa.

E este o professor que hoje recebemos solenemente nesta

Não apenas por isto, contudo, alegra-se nesta noite a nossa Faculdade.

Fábio Comparato não é apenas o estudioso tenaz e culto. E também o advogado consciente e destemido, o administrador frio e eficiente. Ele é ainda, e oxalá o seja sempre, um homem que é capaz de um humor penetrante, às vezes corrosivo, mas que põe a mostra, com um sorriso da mais fina ironia, daquela de que já nos vamos desabituando mercê da vulgaridade crescente que nos assola, as realidades simples da vida, que muitos teimam em esconder atrás de formulações complexas e vazias. 
Apenas para ilustrar esta faceta de sua personalidade, recordaria o preâmbulo com que Fábio Comparato iniciou certa vez uma conferência dirigida a um grupo de homens de empresa.

"Para evitar desde logo - disse ele - os equívocos fundamentais, que frequentemente dificultam a compreensão recípocra de juristas e empresários, principalmente quando os primeiros professam em Universidades, seja-me permitido principiar com a sábia advertência de BERNARd SHaw: 'quem sabe faz, quem não sabe ensina" ("in" Rev. Dir. Mercantil, 5/132).

Ora, quem pode ser melhor professor que aquele que considera uma agravante, e não uma atenuante, a sua própria condição de docente?

"Ridendo castigat mores", é bem verdade; mas Fábio Comparato, que ainda nisto se revela filho desta Academia, o faz com modéstia, sem humilhar os seus contraditores, buscando antes conquistar a sua simpatia, que evocar o seu rancor.

Num ponto apenas o encontramos irredutível, inabalável, temível, fechando como uma fortaleza mas contudente como uma bala.

E quando entram em jogo os direitos fundamentais da pessoa humana.

Lembro-me de uma tarde, já faz alguns anos, em que nos encontramos casualmente aqui perto e caminhamos juntos algumas quadras.

Estávamos ambos indignados pelas notícias que tínhamos do que vinham padecendo os prisioneiros políticos.

FÁBIo chamou minha atenção para o fato de que o germe do nazismo existia dentro de todos nós; que ninguém es- 
tava livre de ceder a ele, de contemporizar com ele, de alimentá-lo pela omissão, ou até mesmo de acabar sendo por ele mortalmente contaminado.

Foi então que percebi, que em Fábio Comparato a luta pela defesa dos direitos da pessoa humana mergulhava suas raízes no mais profundo de sua alma.

Não era a dor pelo padecimento físico, não era a humilhação em face da bestialidade, não era o horror diante da conspurcação da dignidade da pessoa humana; era tudo isto e muito mais: era o sentido da luta crucial, do embate interminável, (da tragédia fundamental do ser humano), da batalha do bem contra o mal.

E nisto, meus senhores, toda a profundidade se revelava da figura de Fábio Comparato, enquanto jurista, enquanto cristão, enquanto homem.

Conhecendo-o, porém, como o conheço, não quero prolongar-lhe o tormento de fazê-lo, por mais tempo, ouvir-me falar de sua pessoa.

Se, para os que me ouvem e o conhecem, falei pouco e fui omisso, sei que para ele já falei demais.

$\mathrm{Na}$ verdade, são pobres as palavras, são toscas, são arremedos da realidade, são seu pálido reflexo.

Na sua pessoa, professor, homenagemos hoje os valores que lhe são caros, os bens culturais e espirituais que constituem as metas de sua vida, pois é em torno desses valores que nos reunimos, como se reuniam os antigos à volta do fogo, nas noites frias dos invernos escuros.

Na comunhão desses bens culturais e espirituais, é que nos tornamos irmãos, nos fortificamos, nos acendemos em nossos corações a chama da esperança, dessa esperança vital 
de que tanto necessitamos para crer ainda, e de novo e outra vez e sempre, na vitória do Direito e na ressurreição da Justiça.

Saiba, caro professor: somos todos irmãos e somos muitos. Mas, porque somos sedentos de saber e de justiça, somos pobres. Temos, porém, em sua companhia, a certeza de possuir a única riqueza verdadeira, pois outra riqueza não há senão a de homens.

"Il n'est de richesse que d'hommes".

\section{Discurso de Posse de Fabio Konder Comparato.}

Impōe a tradição desta Casa, amante de tradições, que, ao atingir o grau máximo da carreira docente, o professor seja recebido, em sessão solene, com saudação e resposta públicas.

Sempre interpretei este ato tradicional, não como homenagem à personalidade do recipiendário, a qual, no meu caso, sem falsa modéstia, não apresenta nenhuma virtude mais assinalada que a distinga da mediocridade ordinária, mas como uma declaração de princípios, uma promessa solene, em uma palavira, um juramento. Do bacharel em Direito exige-se que preste um juramento por ocasião da colação de grau. Por que se haveria de isentar dessa promessa solene io professor de Direito, quando toma assento, definitivamente, junto a seus pares?

Penso que é esta, aliás, a maneira mais digna de responder à saudação que, excessivamente cordial para ser justa e adequada, acaba de proferir o querido amigo Pnofessor José Ignácio Botelho de Mesquita.

Do novo professor titular de Direito, exige-se que diga, publicamente, a que veio, o que pretende e qual a sua concepção da jurisdocência.

E o que desejo fazer neste momento, com total lhaneza, tomando os presentes como testemunhas. 
Tenho por auto-evidente que a função do jurista não se esgota no exímio manejo da técnica normativa, a serviço de quaisquer finalidades; mas que ela só se realiza, de um lado, pela crítica permanente dos valores predominantes da sociedade em que atua e, de outro, pelo trabalho de contínua adaptação da técnica jurídica a esses valores.

Nos primórdios da nossa ciência, a tarefa de pensar o Direito e compor interesses foi algo bem diverso de uma arte normativa desbussolada, axiologicamente cega, como a encontramos no presente. Sob o influxo da filosofia grega, os jurisconsultos romanos conceberam jus civile e jus gentium como manifestações da naturalis ratio, ou seja, de uma ordem imanente ao mundo e à sociedade dos homens, e portanto superior ao arbítrio de governantes, legisladores e magistrados. A racionalidade jurídica, para os prudentes, não se desvinculava dos valores sociais, não se reduzia a uma lógica de conceitos. Se a jurisprudentia era entendida como a ciência do justo e do injusto, ou a arte do bom e do eqüo, segundo duas célebres definições que ainda hoje nos surpreendem, é porque o jus naturale - seu objeto - enquanto tradução normativa dessa razão imanente ao mundo e aos homens, concebia-se como id quod semper aequum ac bonum est (Dig., I, 1, fr. 11).

Ora, esse discernimento constante do que é justo, socialmente bom e equitativo supõe uma ampla compreensão do homem e do: mundo, irredutível às habilidades do leguleio. Os romanos denominaram tal discernimento prudentia, como tradução da frônessis grega, essa sabedoria no agir que, como explicou Aristóteles, não se confunde nem com a ciência natural, cujo objeto são fatos necessários, nem tampouco com a técnica ou arte de fazer, que se subordina a quaisquer fins (Ética a Nicômaco, VI, 5).

Sabedoria no agir, por conseguinte, enquanto o agir se opõe, tanto à contemplação, quanto à fabricação. $O$ jurisprudente, tal como o autêntico zoon politikon, é, pois, o homem 
da vita activa, da vida superiormente humana, que não se limita a um mero cogitar, nem se transforma num simples produzir coisas, mas se expande em atos ou deliberações, isto é, num inter agere. Ora, a deliberação não tem por objeto fatos necessários, mas ações humanas, onde interfere a liberdade.

A era moderna, porém, veio revolucionar, no sentido próprio, essa concepção do homem e da vida. As atividades outrora julgadas desprezíveis - as de fazer e fabricar - passaram a ocupar o lugar eminente do antigo agir. $\mathrm{O}$ advento do homo faber, segundo a feliz expressão cunhada por HENRI BERGSON, transmudou a antiga razão natural e objetiva, a antiga capacidade de discernir os verdadeiros fins do homem e do mundo, em mera aptidão técnica de produzir qualquer resultado; degradou a inteligência em engenhosidade.

As conseqüências políticas dessa revolução são de fácil percepção. $\mathrm{O}$ Estado atual, sob os mais variados regimes políticos, persegue, como valores supremos, a estabilidade, a segurança e a produtividade, isto é, os fins próprios de uma atividade empresarial. Os cidadãos são excluídos, sistematicamente, da vida pública, seja pela repressão, seja pelos métodos mais sutis e menos primitivos da persuasão e da propaganda, para que se consagrem aos negócios privados. $\mathrm{O}$ Estado contemporâneo realizou enfim, com pleno sucesso, o objetivo próprio das antigas tiranias orientais, que o mundo greco-latino sempre denunciou com um misto de horror e desprezo: a transformação definitiva de ágora ou do forum em mercado.

$E$ que o homo faber, tal novo Midas, transforma tudo que toca em instrumentos ou ferramentas; tudo degrada em meios, sem valor intrínseco e independente. E essa instrumentalização universal termina por suprimir o equilíbrio fundamental da vida humana, pela supressão de uma razão de viver. Afinal, como perguntava Lessing aos utilitaristas do seu. tempo, para que serve a utilidade? 
A antecipação, pioneiramente lançada por HoBBes, da sociedade como produto, por assim dizer, da fabricação humana, a modo de um autômato, passou a influenciar, ponderosamente, os séculos posteriores. Tudo pode ser fabricado, até o próprio homem e a sociedade dos homens.

Não há negar, portanto, que a autêntica jurisprudentia encontra graves dificuldades para subsistir na atual civilização. A sua atividade própria de deliberar, na livre interação humana, opõe-se, por demais frontalmente, à instrumentalização da vida, para que o conflito não se manifeste. Ao transpor para o espaço público o seu estilo, o homo faber legitimou a violência, enquanto degradação do poder, como método normal de governo. E preciso não esquecer, com efeito, que a violência insere-se em todo ato de fabricação. A produção de utensílios supõe, em qualquer circunstância, uma anterior destruição da natureza. Acostumado a lidar com a matéria inerte, o fabricante desconhece o diálogo e não tolera resistências. Nesse sentido, é io protótipo do ser apolítico.

Ora, essa concepção violenta do poder foi decisivamente acentuada com a simbiose industrial-militar, que representa o mais importante fenômeno político dos tempos modernos, identificável nos mais variados sistemas de governo, em qualquer parte do mundo. $O$ governar tornou-se sinônimo de comandar, para a fabricação ou produção em tempo de guerra. E a própria atividade legislativa, considerada a parte mais nobre da vida pública, reduziu-se, na expressão consagrada, a um vulgar "fazer leis"

O jurista, como todos os demais profissionais da palavra, foi mobilizado para essa campanha bélico-produtiva, como escriba de comandantes, ou fabricante de normas. E é nessa posição humilhante que habitualmente o vemos trabalhar, a tal ponto que a defesa do imobilismo social passou a ser a função, por assim dizer, natural dos homens do Direito. $\mathrm{Na}$ primeira metade do século passado, Alexis de Tocqueville 
traçou do "legista", ou profissional das leis, um retrato conservador. "O que os legistas apreciam sobre todas as coisas", escreveu, "é a ordem, e a maior garantia da ordem é a autoridade. Não se deve esquecer, aliás, que se eles prezam a liberdade, costumam colocar a legalidade bem acima dela; eles temem menos a tirania do que o arbítrio, e, contanto que o legislador se encarregue, ele próprio, de retirar aos homens sua independência, eles ficam razoavelmente satisfeitos" (De la Démocratie en Amérique).

$\mathrm{O}$ atual século, porém, conheceu algo pior do que as tradicionais autocracias: o Estado totalitário, inimigo até da própria legalidade. $\mathrm{E}$ ainda aí, vimos juristas, engajados a serviço do terror e do arbítrio.

Pois bem, é contra esse servilismo jurídico, pávido e degradante, que prometo atuar, dentro e fora desta Casa do Direito. O próprio do jurisprudente, já disse, é saber deliberar, isto é, julgar e distinguir entre boas e más ações, valorar os atos humanos, compor interesses. Somos todos homens da palavra, e disso devemos nos orgulhar, a despeito de todas as crufas do homo faber contra o que se lhe afigura uma parolagem improdutiva. Pois a verdadeira ação pública, no seu sentido amplo, não se realiza pela violência e sim pela palavra. As palavras justas, proferidas no momento oportuno, como as sentenças de um magistrado, são ações do mais alto valor. Somente a violência bestial é muda, como salientou HaNNAH ARENDT, e é por isso mesmo que ela jamais se manifesta com grandeza.

Qualquer que seja a sua posição na sociedade - como legislador, magistrado, advogado, consultor ou docente - o jurisperito atua como julgador.

$\mathrm{O}$ jurisprudente incapaz de julgar a sociedade em que vive, ou que se recusa a tomar partido, com receio dos poderosos do momento, é um prevaricador, a merecer a pena de atimia, que a democracia ateniense reservava aos cidadãos de- 
sinteressados da vida pública. O seu destino, como simbolizou o Poeta, não é nem mesmo o inferno, do qual não foi julgado digno pela sua neutralidade desumana, mas o vestíbulo do inferno, onde persegue sem descontinuar, em mal sofrido desespero, o que a sua ignávia se recusou a eleger, durante a vida terrena. "Têm a alma triste dos que viveram, sem infâmia nem louvor", misturados ao coro dos anjos que não se revoltaram nem tampouco se pronunciaram em favor de Deus ou de Lúcifer. Questi hon hanno speranza di morte, e la lor cieca vita é tanto bassa, che 'invidiosi son d'ogni altra sorte (Divina Commedia, Inferno, III) .

O que se espera de um professor de Direito, no Brasil de hoje, não é a repetição enfadonha de dogmas oficiais, nem mesmo a exposição, ainda que profunda ou brilhante, de um pensamento teorético, ou a engenhosidade técnica na solução de problemas. O que se espera, antes de tudo, é uma declaração de princípios e um julgamento do nosso sistema jurídico à luz de tais princípios.

E esse julgamento; meus Senhores, que desejo prolatar, aqui e agora, em público e raso, ao ter a honra de ingressar, oficialmente, nesta douta Congregação.

Entendo que a ordenação jurídica brasileira padece, desde as origens, de grave ilegitimidade, porque as suas normas, estabelecidas sem o necessário consenso público, aparecem, no conjunto, desligadas da situação existencial dos jurisdicionados.

Dessa ilegitimidade, a mais sentida e mais freqüentemente denunciada é, sem dúvida, a da nossa organização política. Seria talvez supérfluo relembrá-lo, uma vez mais, se ela não fosse a causa mais profunda de nossos males.

Há cento e cinqüenta anos se vem ensaiando a democracia neste país, sem nunca haver existido, na realidade política, governo da maioria e proteção dos direitos da minoria, isto é, 
sem autêntica soberania popular e sem efetiva garantia aos direitos fundamentais da pessoa humana. A evolução recente veio tornar ainda mais vincado o divórcio entre Estado e sor ciedade, entre povo e minoria no poder. Sob a invocação da liberdade e com proclamações anti-totalitárias, instituíurse o abuso de poder como forma ordinária de governo.

Ora, a missão dos jurisprudentes, no caso, não se esgota no protesto que, de resto, tem sido bem tímido, contra a subversão da justiça e a corrupção do poder político, com as conseqüências lamentáveis que todos conhecemos.

O que se espera de homens de pensamento é também uma análise das causas que nos têm conduzido a essa situação.

Elas se resumem, a meu ver, a uma divergência persistente entre o direito positivo e os costumes do povo. ARISTóteles já havia assinaladio que cada Estado tem seus costumes, do qual dependem sua conservação e mesmo o seu estabelecimento. São os costumes democráticos que fazem a democracia, e não o contrário. Montesquieu retomou a mesma idéia, colocando-a como princípio das leis. E Tocqueville descobre-a como um ponto central de seu espírito, divisando-a, como escreveu, ao cabo de todos os seus pensamentos.

Ora, manifestamente, os costumes do povo brasileiro nunca foram democráticos. $\mathrm{O}$ povo sempre se acomodou de sua posição à margem da vida pública. $\mathrm{O}$ espírito crítico jamais deitou raízes entre nós. Não existe uma virtude igualitária, como ideal de vida.

Quandio Tomé de Souza desembarcou na Bahia, em 1549, munido do seu famoso Regimento do Governo, e flanqueado de um ouvidor-mor, um provedor-mor, clero e soldados, a organização político-administrativa do Brasil, como país unitário, principiou a existir. Tudo fora minuciosamente preparado e assentado, em oposição ao descentralismo feudal das capitanias hereditárias. Notava-se apenas, como disse um his- 
toriador, uma ligeira ausência: não havia povo. A população indígena, estimada na época em um milhão e meio de almas, não constituía, obviamente, o povo do novel Estado; tampouco o formavam os 1.200 funcionários - civis, religiosos e militares - que acompanharam o Governador Geral. Tivemos Estado antes de ter povo.

Foi este, na verdade, o primeiro ato, de uma longa série de eventos, em que começamos pelo fim, numa incontida impaciência de colher os frutos antes de plantar as árvores.

"Foi-se vendo pouco a pouco", escreveu o jovem Alceu Amoroso Lima, há meio século, "e até hoje o vemos ainda com surpresa, por vezes - que o Brasil se formara às avessas, começara pelo fim. Tivera Coroa antes de ter Povo. Tivera parlamentarismo antes de ter eleições. Tivera escolas superiores antes de ter alfabetismo. Tivera bancos antes de ter economias. Tivera salōes antes de ter educação popular. Tivera artistas antes de ter arte. Tivera conceito exterior antes de ter consciência interna. Fizera empréstimos antes de ter riqueza consolidada. Aspirara a potência mundial antes de ter a paz e a força interior. Começara em quase tudo pelo fim. Fora um obra de inversão, produto (. .) de um longo oficialismo".

Debalde procura-se o povo, nos principais fastos de nossa História. Ele teima em permanecer ausente, privado de palavra. $€$ assim mesmo que VIEIRA o descreve, no sermão da visitação de Nossa Senhora, pregado por ocasião da chegadal à Bahia do Marquês de Montalvão,! Vice-Rei do Brasil, em junho de 1640: "Ut facta est vox sallutationis tuae in auribus meis, exultavit in gaudio infans. Comecemos por esta última palavra", propôs o grande pregador. "Bem sabem os que sabem a língua latina, que esta palavra, infans, infante, quer dizer o que não fala. Neste estado estava o menino Batista, quando a Senhora o visitou, e neste esteve o Brasil muitos anos, que foi, a meu ver, a maior ocasião de 
seus males. Como o doente não pode falar, toda a outra conjectura dificulta muito a medicina. (...) O pior acidente que teve o Brasil em sua enfermidade foi o tolher-se-lhe a fala: muitas vezes se quis queixar justamente, muitas vezes quis pedir o remédio de seus males, mas sempre lhe afogou as palavras na garganta, ou o respeito, ou a violência; e se alguma vez chegou algum gemido aos ouvidos de quem o devera remediar, chegaram também as vozes do poder, e venceram os clamores da razão"

Dessa advertência, porém, pouco cuidaram os governantes. Um século após, um outro Vice-Rei, o Marquếs de Lavradio, no relatório deixado a seu sucessor, aconselhava-o, tranqüilamente, a "não fazer algum caso das murmurações do povo".

A nossa independência que, paradoxalmente, não foi resultado de uma revolta do povo brasileiro contra o rei de Portugal, mas, ao contrário, do povo português contra o rei no Brasil, não suscitou - é escusado dizê-lo - o menor entusiasmo popular. Um observador judicioso, como SaINTEHilaire, pôde testemunhar: "A massa do povo ficou indiferente a tudo, parecendo perguntar como o burro da fábula: - Não terei a vida toda de carregar a albarda?"

A mesma cena, com personagens diferentes, é repetida 67 anos depois, no 15 de novembro. "O povo assistiu àquilo bestializado, atônito, surpreso, sem conhecer o que significava", lê-se na carta, tantas vezes citada, de Aristides Lobo a um amigo. "Muitos acreditavam sinceramente estar vendo uma parada. Era um fenômeno digno de ver-se". E acrescentava logo, como para justificar de alguma sorte o seu republicanismo decepcionado: "O entusiasmo veio depois, veio mesmo lentamente, quebrando o enleio dos espíritos".

Tudo isso não impediu, como sabido, que a proclamação dos memibros do Governo. Provisório principiasse pela invocação do povo; o que levou o representante diplomático 
norte-americano no Rio de Janeiro, embora francamente favorável ao novo regime, a deplorar, em despacho endereçado ao Secretário de Estado, em Washington, em 17 de dezembro de 1889 , o pouco caso que assim se fazia da vontade popular.

Seria ousado pretender que o nosso século trouxe alguma alteração de monta nesse quadro tradicional. A única mudança, talvez, tenha sido o temor de que o povo venha, algum dia, a tomar uma iniciativa. O próprio movimento de 1930 , por muitos reconhecido como data marcante de nossa evolução político-social, foi desencadeado sob o slogan do Presidente de Minas, Antonio Carlos: "Façamos a revolução antes que o povo a faça".

A tradição do patronato político é, sem dúvida, uma das mais enraizadas em nossa História. Contra ela, de pouco vale proclamar enfaticamente, em todas as Constituições que se sucederam a partir de 1934, que "todo o poder emana do povo e em seu nome será exercido".

Se isto sucede com a vontade popular, algo de semelhante encontramos do lado da igualdade, outro fundamento do regime democrático.

Montesquieu muito insistiu no fato de que não há democracia que possa medrar, sem um generalizado amor da igualdade e da frugalidade, como base natural para a virtude política.

Essas qualidades parecem estranhas ao nosso modo de viver. Clovis Bevilágua afirmou, algures, que o nosso sistema jurídico se diferenciaria, fundamente, dos sistemas europeus, pelo fato de a aristocracia não haver deitado raízes em nosso solo. Faltou, porém, ao notável jurisconsulto a percepção de que o princípio aristocrático pode, perfeitamente, realizar-se sem armas e baronias. No seio dos povos ibéricos, ele decorre de um individualismo exacerbado, pelo qual, ainda 
que inconscientemente. recusamos em qualquer outro concidadão a igualdade de condiçōes com cada um de nós.

Herdeiros da tradição ibérica, somos um povo que ama os privilégios, o tratamento pessoal e diferençado, de que a instituição nacional do "jeitinho" constitui a demonstração mais convinoente.

Nesse contexto, a extrema desigualdade econômica oposta àquela geral frugalidade de que falava MonTEsQuieu - não se nos apresenta como escanclalosa ou lamentável. Parece-nos mesmo uma questão secundária.

Por outro lado, o espírito associativo jamais existiu entre nós. O nosso sentimento de solidariedade se manifesta espontâneo e até caloroso nas relações de afeto, entre parentes e amigos; jamais no campo dos empreendimentos impessoais e racionais. Daí o fato de que o princípio constitucional de isonomia sempre se nos afigurou um refinado embuste, por trás do qual deveria esconder-se algum protecionismo. Todos são iguais perante a lei, continuam a proclamar as nossas cartas políticas. Mas há sempre alguém mais igual do que os outros; disso estamos todos convencidos.

Dessa carência atávica de associação racional e sólida, em todos os níveis sociais - do sindicato ao partido político decorre o fato de que o único princípio unificador da nossa Sociedade é o Estado; e que a vida política, à falta de um ponto de equilíbrio mediano, oscila constantemente entre os extremos da anarquia e da autocracia. "As ditaduras e o Santo Ofício", como escreveu SÉrgio Buarque de Holanda, "parecem constituir formas tão típicas do caráter ibérico, como a inclinação à anarquia e à desordem".

Apesar de tudo, porém, fomos engendrados pelo Ocidente europeu, por uma civilização que conheceu a democracia e o respeito à pessoa humana, como superior e anterior axiologicamente falando - à raça, à classe, à nação. 
Como explicar, então, essa degenerescência em relação às nossas matrizes?

A razão está, como vários assinalaram, na total ausência de espírito crítico, cujo aparecimento, no Ocidente, inaugura a cultura moderna. Aquela "crise da consciência européia", como a denominou Paur. Hazard, irrompida desde 1680, e que deu origem ao iluminismo e aos direitos do homem, passou ao largo da península ibérica.

A expressão do antigo professor do Collège de France é feliz, pois sintetiza o fenômeno histórico em seu duplo significado. Com efeito, "crítica" provém de "crise", vocábulo correlato a "crivo", com a acepção original grega de ação ou faculdade de distinguir, de eleger, de decidir. A crítica é, por conseguinte, a arte de julgar. Kritês é o árbitro.

Reencontramos, aqui, mais uma vez, aquela aptidão decisória que, na sua ampla compreensão racional e valorativa, é a qualidade própria e eminente do jurista.

Ora, no momento em que o homem europeu teve a ousadia de passar pelo crivo da razão individual a tradição, o dogma e a ordem estabelecida, produziu-se uma autêntica ruptura na evolução histórica do Ocidente, uma verdadeira crise no sentido moderno do vocábulo.

E nesse momento, precisamente, que a península ibérica se desvia da rota ocidental e dá início a um inevitável processo de decadência, em todos os setores. $O$ fenômeno é impressionante, pelo contraste violento que representa em relação à centúria imediatamente anterior, o grande século dos descobrimentos. Então, um pequeno povo de meio milhão de habitantes deixava estupefata a humanidade, ao dar sozinho "novos mundos ao mundo", ao livrar, com isto, o Ocidente europeu, como reconhece um dos expoentes da moderna historiografia, daquela Wüstungen que representou o mais prolongado colapso econômico de sua história (IMMANuel WaLlerstein, 
The Modern World-System, Capitalist Agriculture and the Origins of the European World-Economy in the Sixteenth Century) Um punhado de marinheiros ousou, então, desafiar a tradição dogmática, provando, com um "saber só de experiências feito", a verdade simples de que a terra é redonda. "... Nestas coisas", escreveu Duarte Pacheco Pereira, no Esmeraldo de Situ Orbis, "a nossa nação dos Portugueses precedeu todos os antigos e modernos em tanta quantidade, que sem repreensão podemos dizer que eles, a nosso respeito, não souberam nada" Ora, quando os demais povos do Ocidente Europeu atingiam, somente um século e meio após, essa atitude epistemológica, é justamente então que a nação portuguesa dá o salto mortal de que falou Antero, passando, sem transições, da Renascença ao Reino da Estupidez. "A uma geração de filósofos, de sábios, de artistas criadores, sucede a tribo vulgar dos eruditos sem crítica, dos acadêmicos, dos imitadores".

Portugal $-e$, por via de conseqüência, o Brasil - tal como a Rússia, aliás, não conheceram, ou deixaram fenecer, o racionalismo crítico; não foram afetados pela crise da consciência européia dos séculos XVII e XVIII. É daí que decorre, entre outros efeitos, a falta de tolerância e de aceitação do relativismo político; sem as quais não há pluralismo democrático.

Uma das causas determinantes desse resultado, no que concerne aos povos ibéricos, malgrado as reticências dos atuais historiadores, parece-me ter sido a peculiar função política assumida, no Estado espanhol e no português, pela instituição do Santo Ofício.

Com efeito, a Inquisição ibérica não foi uma instituição puramente religiosa, mas eminentemente política. Pior: ela não se inseriu no Estado como órgão governamental, nem tampouco na Igreja como órgão pontifício, mas subsistiu como um poder autônomo, que nomeava seus próprios funcionários, sustentava seus próprios clientes e vivia de receitas privativas. 
Creio que não foi, ainda, suficientemente ressaltado o fato de que a Inquisição ibérica representou uma antecipação do Estado totalitário e ideocrático do século XX, enquanto distinto das simples ditaduras ou das tradicionais autocracias. No funcionamento do Santo Ofício, encontramos como peça central o princípio do "inimigo objetivo", que não se define por ações nem mesmo por tentativas, mas pelo fato de ser um "portador de tendências", assim como outros são "portadores de moléstias" (HanNah ARENDT)

Daí a substituição do conceito de crime certo, ou mesmo provável, pelo de crime possível. O inimigo objetivo é aquele que seria capaz de cometer os atos de que é acusado. Isto basta.

Daí, finalmente, o entendimento da confissão - qualquer ção como dever público e o estabelecimento da noção de culpabilidade por associação, envolvendo o círculo de amigos e familiares do acusado.

Daí, finalmente ro entendimento da confissão - qualquer que tenha sido a maneira de extraíla - como elemento central e indispensável de todo processo; uma espécie de confirmação a posteriori do crime possível. No processo inquisitorial, todos os réus se definem em função da confissão. Há os "negativos", que se recusam a reconhecer suas faltas; os "diminutos", que se limitam a reconhecer parte delas; os "fictos ou simulados", que se apressam em confessar falsamente, para escapar à tortura; os "revogantes", que se retratam, posteriormente, do que declararam sob os tormentos; afinal, os veros e próprios confitentes. Todos eles, confundidos na mesma condenação e no mesmo desprezo.

Seria inverossímil que uma instituição que marcou tão fundamente, durante mais de três séculos, a vida qüotidiana dos povos ibéricos e suas colônias, não continue a influenciar, ainda hoje, os nossos hábitos políticos. 
Eis aí, minhas Senhoras e meus Senhores, por que os costumes mais arraigados, ou a maneira de ser do nosso povo, não me parecem ter favorecido o estabelecimento de um autêntico regime democrático entre nós. O Brasil converte-se agora, com a fé do neófito, ao instrumentalismo e à sociedade de consumo, privado dessa formação crítica, que lhe permitiria resistir aos delírios do homo faber.

Seria tolo engano, no entanto, tomar essa minha apreciação como produto de um pessimismo estéril. Um Professor pessimista é, a meu ver, uma contradição in adjecto, pois nega a possibilidade de transformação do mundo. $\mathrm{O}$ ato de educar supõe a liberdade do educando, a sua capacidade de criação renovadora, o fiat recorrente a cada nascimento de um ser humano. No caso brasileiro, particularmente, a docência é um ato constante de fé na juventude, cuja febre, como disse excelentemente BERNANOS, é o único fator que mantem o mundo em sua temperatura normal.

Por isso mesmo, admitir que os costumes condicionem o Direito não é, absolutamente, aderir à "teoria do medalhão" de Machado de Assis, com o acacianismo do "antes das leis, reformemos os costumes" Não há aqui cabida para interpretações mecanicistas, do gênero unilateral de causa a efeito, ou de estrutura e super-estrutura; mas, antes, uma dialética de implicações recíprocas. As leis também agem sobre os costumes, assim como estes condicionam a aplicação daquelas. A idéia da legislação como pedagoga, encarregada de formar e educar os homens, tal como Sócrates nô-la ápresenta, no "Criton" de Platã̃o, é uma das mais fecundas tradições da civilização ocidental. Por isso mesmo, a edição de leis deformantes, como a de supressão permanente de garantias individuais, por exemplo, representa uma corrupção de costumes.

E neste sentido que se revela a excelência ímpar da missão de Professor de Direito, atuando criticamente, a um tempo, sobre as fontes da legislação e sobre o espírito jurídico 
das novas gerações; missão augusta de educador - e não de mero instrutor - que confia no Homem e respeita a sua intangibilidade essencial, a exemplo do próprio Deus, segundo nos assevera o poeta:

"Conheço bem o homem, diz Deus.

Fui eu quem o fez. E um ser curioso.

Porque nele atua a liberdade, que é o mistério dos mistérios". 